\section{Adrenergic Blocking Properties of some New Benzodioxanes}

Since the work of Fourneau and Bovet ${ }^{1}$ on the adrenergic properties of benzodioxanes, numerous publications ${ }^{2,3}$ have appeared, the most recent being that of Augstein and Green ${ }^{4}$.

In an attempt to correlate structure and adrenolytic and/or adrenergic neurone-blocking properties, a series of substituted 1: 4 benzodioxanes were prepared with the general formula:

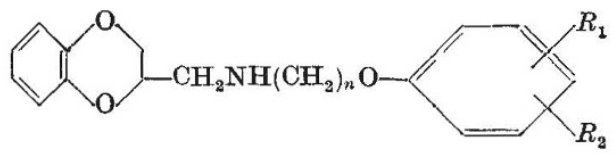

$R_{1} R_{2}=\mathrm{H}$, halogen atom, methoxy or methyl; $n=$ an integer from 2 to 4 .

We are now reporting the adrenolytic and adrenergic blocking properties of the two most potent members of the series--4085 and 4101:

$$
\text { - } \mathrm{CH}_{2} \mathrm{NH}\left(\mathrm{CH}_{2}\right)_{2} \mathrm{O}
$$

Both compounds were found to protect against the lethal effects of adrenaline in mice and the $E D_{50}$ by the oral route was $3.6 \pm 0.6 \mathrm{mg} / \mathrm{kg}$ for 4085 and $0.22 \pm 0.03$ $\mathrm{mg} / \mathrm{kg}$ for 4101 .

Further tests carried out in the anaesthetized rat showed that these compounds were potent long-acting blockers of adrenaline and noradrenaline. In the cat it was found that only 4.101 antagonized contraction of the nictitating membrane to stimulation of the pre- and post-ganglionic cervical sympathetic fibres. Both compounds abolished the response to adrenaline, noradrenaline and splanchnic stimulation.

These compounds were prepared by conventional methods which will be described with their pharmacology in detail elsewhere.

Steps have also been taken to obtain patent protection for these and other compounds in the series.
H. FENTON
P. N. GREEN
M. Shapero
Catherine Wilson

Ward Blenkinsop and Co. Ltd.,

Research Laboratories, Fulton House,

Wembley, Middlesex.

\section{${ }^{1}$ Fourneau, E., and Bovet, D., Arch. Int. Pharmacodyn., 46, 178 (1933). ${ }^{2}$ Bovet, D., and Bovet-Nitti, F., Structure et Activite Pharmacodynamique des . \\ ${ }^{3}$ Nickerson, M., J. Pharmacol. Exp. Ther., ii, 95, 27 (1949). \\ "Augstein, J., and Green, S. M., Nature, 201, 628 (1964). \\ Adrenergic Alpha- and Beta-receptors in the Mouse Iris}

IN the course of comprehensive studies of the mechanism of sympathetic function using the mouse iris as a working model we have demonstrated adrenergic $\alpha$ - and $\beta$-receptors and determined their dynamic properties under the influence of pharmacological agents.

The experimental method involved the determination of the mydriatic effect $(E=$ maximal mydriatic diameter minus diameter before injection $\left(D_{I}=0.24 \pm 0.016\right.$

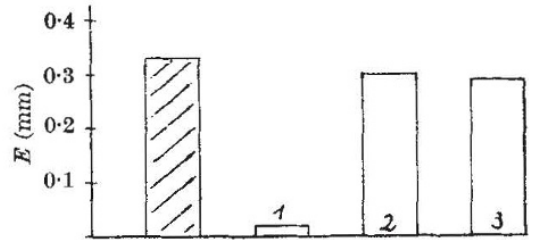

Fig. 1. Influence of $\alpha$ - and $\beta$-receptor-antagonists on the action of norepinephrine. Hatched column, $0 \cdot 1 \quad \mu \mathrm{g} / \mathrm{g}$ norepinephrine-HCl; column $1,6 \cdot 0 \mu \mathrm{g} / \mathrm{g}$ phenoxymn $3,2.5 \mu \mathrm{g} / \mathrm{g}$ dimethyldideshydroxyisoproterenol- $\mathrm{HCl}$
colum

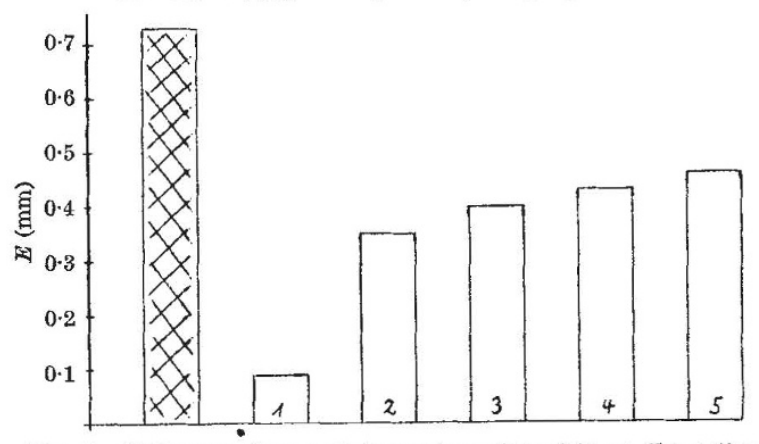

Fig. 2. Influence of $\alpha$ - and $\beta$-receptor-antagonists on the action of epinephrine. Hatched column, $0.05 \mu \mathrm{g} / \mathrm{g}$ epinephrine- $\mathrm{HCl}$; column 1 , $6.0 \mu \mathrm{g} / \mathrm{g}$ phenoxybenzamine-HCl; column $2,2.5 \mu \mathrm{g} / \mathrm{g}$ 'Inderal'; column 3 , $10.0 \mu \mathrm{g} / \mathrm{g}$ pronethalol; column $4,5.0 \mu \mathrm{g} / \mathrm{g}$ dichlorisoproterenol-HCl; column $5,6.0 \mu \mathrm{g} / \mathrm{g}$ dimethyldideshydroxyisoproterenol-HCl

$\mathrm{mm})$ ) according to Pulewka ${ }^{1}$ on male mice of an average weight of $25 \mathrm{~g}$, breed NMRI-Tübingen.

Intravenous injection of $0.1 \mu \mathrm{g} / \mathrm{g}$ norepinephrine-HCl causes a mydriatic effect, $E=0.33 \mathrm{~mm}$. This effect was blocked, to the extent of 94 per cent, by subcutaneous injection of the $\alpha$-receptor antagonist phenoxybenzamine$\mathrm{HCl}(N$-benzyl- $N$-phenoxyisopropyl- $\beta$-chlorethylamine$\mathrm{HCl}$; dibenzyline) $30 \mathrm{~min}$ before treatment, $6 \mu \mathrm{g} / \mathrm{g}$ $(P<0.001, n=40)$. This dibenzyline injection similarly blocks to the extent of 88 per cent the mydriatic effect, $E=0.73 \mathrm{~mm}$, of intravenous injection of $0.05 \mu \mathrm{g} / \mathrm{g}$ of epinephrine-HCl $(P<0.001, n=40)$. These effects are shown in Figs. 1 and 2.

Intravenous injection of $20 \mu \mathrm{g} / \mathrm{g}$ isoproterenol-HCl has a mydriatic effect, $E=0.5 \mathrm{~mm}$. This effect was decreased by subcutaneous injection, $30 \mathrm{~min}$ before treatment, of $\beta$-receptor antagonists. 'Inderal' (1-isopropylamino-3-(1-naphthyloxy)-2-propanol-HCl; 'T.C.I. 45,520') in doses of $2.5 \mu \mathrm{g} / \mathrm{g}, 5 \mu \mathrm{g} / \mathrm{g}$, or $10 \mu \mathrm{g} / \mathrm{g}$ exerted a blocking effect to the extent of 64 per cent, 74 per cent and 74 per cent respectively $(P<0.001, n=40$ in each case). Pronethalol (2-isopropylamino-1-(2-naphthyl)ethanol-HCl; 'nethalide'; 'Alderlin') at a dosage of $10 \mu \mathrm{g} / \mathrm{g}$ had an inhibitory effect of 58 per cent $(P<$ $0.001, n=40)$. Dichlorisoproterenol-HCl $\quad\left(1-\left(3^{\prime}, 4^{\prime}-\mathrm{di}\right.\right.$ chlorphenyl)-2-isopropylamino-ethanol-HCI; DCI) at a dosage of $5 \mu \mathrm{g} / \mathrm{g}$ had an inhibitory effect of 54 per cent $(P<0.001, n=40)$. Dimethyldideshydroxyisoproterenol-HCl ('H 13/57') at a dosage of $6 \mu \mathrm{g} / \mathrm{g}$ caused 35 per cent inhibition $(P=0.01-0.002, n=40)$. This mydriatic effect was not significantly altered by a similar prior injection of $6 \mu \mathrm{g} / \mathrm{g}$ phenoxybenzamine-HCl (see Fig. 3).

After subcutaneous injection (30 min before treatment) of $6 \mu \mathrm{g} / \mathrm{g}$ phenoxybenzamine-HCl plus $2.5 \mu \mathrm{g} / \mathrm{g}$ 'Inderal', intravenous injection of $0.05 \mu \mathrm{g} / \mathrm{g}$ epinephrine-HCl no longer produced any mydriatic effect (inhibition $=100$ per cent).

A prior subcutaneous injection of $5 \mu \mathrm{g} / \mathrm{g}$ 'Inderal' or $2.5 \mu \mathrm{g} / \mathrm{g}$ dimethyldideshydroxyisoproterenol-HCl $30 \mathrm{~min}$ before treatment had no significant effect on the mydriatic norepinephrine reaction (see Fig. 1).

The mydriatic effect of epinephrine was reduced through subcutaneous injection (30 min before treatment): of $2.5 \mu \mathrm{g} / \mathrm{g}$ 'Inderal' by 52 per cent $(P<0.001, n=40)$, of $10 \mu \mathrm{g} / \mathrm{g}$ pronethalol by 45 per cent $(P<0.001, n=40)$, 